\author{
한우에 대한 현미의 사료가치 평가 \\ 오영균* · 김경훈* · 최창원* · 강수원* · 정일병* · 노환국** \\ 축산연구소*, 한국농업전문학교**
}

\title{
Evaluation of Feeding Value of Brown Rice in Korean Native Beef Steers (Hanwoo)
}

\author{
Y. K. Oh*, K. H. Kim*, C. W. Choi*, S. W. Kang*, I. B. Chung* and W. G. Nho** \\ National Livestock Research Institute, RDA*, Korea National Agricultural College**
}

\begin{abstract}
The present study was conducted to evaluate feeding value of brown rice in Korean native beef steers (Hanwoo) fed concentrates and orchardgrass hay (50:50 on a wet basis) as a basal diet. Either 50\% or $100 \%$ of corn in concentrates was substituted for brown rice, and ruminal fermentation characteristics, in situ degradability of feeds and in vivo digestibility of concentrate were investigated. The digestibility and nutritive values of corn and brown rice feeds were similar, whereas rumen degradability of brown rice was higher than that of corn. Compared with corn-based diets, the brown rice substitution decreased $(\mathrm{P}<0.05)$ ruminal $\mathrm{NH}_{3}-\mathrm{N}$ concentration, but did not affect rumen $\mathrm{pH}$. Total volatile fatty acid content in ruminal digesta for the corn based diet was higher than those for the brown rice-contained diets. The brown rice substitution increased $(\mathrm{P}<0.05)$ the ratio of ruminal acetic acid to propionic acid $(\mathrm{A} / \mathrm{P})$ compared with corn-contained diets.

Present results indicate that corn might nutritionally be substituted for brown rice as cattle feeds. In addition, we expect that relatively high $\mathrm{A} / \mathrm{P}$ with brown rice may produce affirmative effects in rumen physiological aspect, particularly under the grain based feeding system for beef cattle in Korea.
\end{abstract}

(Key words : Brown rice, Hanwoo steer, Feeding value, Rumen fermentation)

$$
\text { I. 서 론 }
$$

우리나라의 축산업은 축산선진국과 비교하여 사료비를 포함한 가축생산비의 부담으로 외국 의 축산물에 비하여 경쟁력이 떨어지는 실정이 고 한편으로는 국내 쌀 소비량 감소에 따른 쌀 재고량이 누적되어 쌀을 가축사료로 사용하는 것이 신중하게 검토되고 있다. 우리나라와 유 사한 상황에 있는 일본의 경우는 1971년부터 재고 쌀 처분차원에서 쌀의 사료가치 평가연구 를 수행하여 왔으며, 1990년부터 재고 쌀을 가 축사료로 이용하고 있다. 이와 같은 상황에서
국내에서도 쌀 소비촉진뿐 아니라 가축의 사료 자원 확보를 위하여 쌀을 이용한 가축사료화 연구의 필요성이 대두되고 있다. 한편 가축에 대한 쌀의 사료가치 연구는 국내에서 생산된 벼, 현미 및 백미에 대하여 차 등(1998)에 의해 최초로 이루어졌으나 면양을 이용한 것이고 소 를 대상으로 한 연구는 없는 실정이다.

따라서 본 연구는 배합사료 내 옥수수 $50 \%$ 와 $100 \%$ 를 현미로 대체하여 반추위 발효성상, in situ 영양소 분해율 및 in vivo 전장소화율을 비교 측정함으로서 반추가축에 대한 현미의 사료가치 와 반추위 발효에 미치는 영향을 평가하였다.

Corresponding author : Y. K. Oh, National Livestock Research Institute, R.D.A., Omockchun-Dong, Kwonsun-Gu, Suwon 441-350 Korea.

Tel : 031-290-1665, E-mail : oh665@rda.go.kr 


\section{․ 재료 및 방법}

\section{1. 공시동물 및 사양관리}

반추위 cannula를 장착한 거세한우 6두(평균 체중: $454.5 \mathrm{~kg}$ )를 이용하여 nylon bag 소화시험 과 반추위 발효시험을 수행하였으며, in vivo 소화율 측정을 위하여 미장착 거세한우 6두(평 균체중 $495 \mathrm{~kg}$ )를 공시하여 계류 장치가 장착된 우사에서 수용하였다. 사료 급여량은 배합사료 급여구에서는 풍건물 기준으로 일일 배합사료 와 오차드그라스를 각각 $3.5 \mathrm{~kg}$ 씩 아침 저녁으 로 1일 2회(07:00와 18:00)로 분할급여 하였
으며 물은 자유채식시켰다.

\section{2. 공시사료 및 시험설계}

본 시험에 사용한 현미는 99년 중국산으로서 옥수수에 비해 단백질, 지방, 섬유질 함량이 다 소 낮았으나 NFE(가용무질소물) 함량은 유사하 였다(Table 1). 가용무질소물은 전분을 비롯한 당류 성분을 나타낸 것으로서 현미의 에너지가 는 옥수수와 거의 동등할 것으로 예측되었으 며, 사료 급여 전 일정량의 사료를 채취하여 분석한 시험사료의 칼로리도 처리구간 유의적 인 차이를 보이지 않았다(Table 2).

Table 1. Comparison of chemical composition of brown rice and corn (\% DM basis)

\begin{tabular}{lccccc}
\hline Items & Moisture & Crude protein & Ether extract & Crude fiber & Nitrogen free extract \\
\hline \hline Brown rice (A) & 13.72 & 8.17 & 2.36 & 1.38 & 86.76 \\
Corn (B) & 14.11 & 8.91 & 4.33 & 3.06 & 86.46 \\
A/B (\%) & - & 92 & 55 & 45 & 100 \\
\hline
\end{tabular}

Table 2. Formula and chemical composition of the experimental diets

\begin{tabular}{|c|c|c|c|}
\hline \multirow{2}{*}{ Items } & \multicolumn{3}{|c|}{ Brown rice substitution levels for corn (\%) } \\
\hline & 0 & 50 & 100 \\
\hline \multicolumn{4}{|l|}{ Ingredients } \\
\hline Corn & 50.00 & 25.00 & - \\
\hline Brown rice & - & 25.00 & 50.00 \\
\hline Wheat bran & 35.00 & 35.00 & 35.00 \\
\hline Soybean meal & 5.50 & 5.50 & 5.50 \\
\hline Corn germ meal & 7.00 & 7.00 & 7.00 \\
\hline Limestone & 1.813 & 1.813 & 1.813 \\
\hline Calcium phosphate & 0.087 & 0.087 & 0.087 \\
\hline $\mathrm{NaCl}$ & 0.40 & 0.40 & 0.40 \\
\hline Vit.-Min. Premix ${ }^{1)}$ & 0.20 & 0.20 & 0.20 \\
\hline Total & 100 & 100 & 100 \\
\hline \multicolumn{4}{|l|}{ Chemical composition $^{2)}$} \\
\hline Dry matter (\%) & 85.20 & 86.04 & 85.07 \\
\hline Crude protein (\% DM) & 12.32 & 13.44 & 13.01 \\
\hline Ether extract (\% DM) & 2.15 & 2.72 & 2.97 \\
\hline Crude fiber (\% DM) & 3.50 & 3.92 & 4.13 \\
\hline Ash (\% DM) & 3.67 & 3.93 & 3.21 \\
\hline Cal (kcal/g) & $3,764.0$ & $3,786.5$ & $3,836.5$ \\
\hline
\end{tabular}

1) Provided the following per kilogram of diet : Vitamin A 2,650,000 IU, Vitamin $\mathrm{D}_{3}$ 530,000 IU, Vitamin E 1,050 IU, B.H.T 10,000 mg, oxo 4,400 mg, manganese 4,000 mg, zinc 4,400 mg, iron 13,200 mg, copper 2,200 mg, cobalt 4,400 mg 2) Analysis value. 
시험구는 옥수수 비율이 $50 \%$ 인 배합사료 (Table 2) 급여구를 대조구(현미 0\%)로 하고 옥 수수의 $50 \%$ 를 현미로 대체 급여한 구(현미 $50 \%$ )와 현미로 $100 \%$ 를 대체 급여한 구(현미 $100 \%)$ 로 하였다.

\section{3. 조사항목 및 방법}

\section{1) In vivo 소화율 측정}

In vivo 소화시험은 6 두의 공시축을 이용하여 two $3 \times 2$ incomplete design으로 수행하였으며 period 별 시험기간은 예비시험(14일)과 본 시 험 5일간 수행하였다.

소화율 측정을 위해서 분은 오전 사료급여 전에 무게를 달아 매일 총배분량의 $10 \%$ 를 수 거하여 분석 시까지 냉장고에 보관하고, 본 시 험 종료 시 일일 수거한 시료를 잘 혼합한 후 그 중 $500 \mathrm{~g}$ 을 대표 시료로 이용하였다. 이 대 표 시료는 $60^{\circ} \mathrm{C}$ dry oven에서 72 시간 건조시킨 후 $2 \mathrm{~mm}$ screen이 장착된 Wiley mill로 분쇄한 후 분석용 시료로 사용했다.

\section{2). Nylon bag 소화시험}

Nylon bag 소화시험은 반추위 cannula가 장착 된 한우 3 두에 옥수수와 현미를 각 시간대별 $(0 \mathrm{~h}, 3 \mathrm{~h}, 6 \mathrm{~h}, 9 \mathrm{~h}, 12 \mathrm{~h}, 24 \mathrm{~h})$ 로 각 시료를 두당 2 개씩 투입하여 6반복하였다. 시험사료의 반추 위내 분해율 측정은 bag size가 가로 $9 \mathrm{~cm}$, 세 로 $20 \mathrm{~cm}$ 인 nylon bag(pore size $45 \mu \mathrm{m}$ )에 분쇄 한 시료 약 $5 \mathrm{~g}$ 을 담고, nylon bag 입구를 nylon 끈으로 묶은 후 $39 \sim 40^{\circ} \mathrm{C}$ 의 물에 담근 후 반추 위 cannula를 통해 반추위의 ventral sac부분에 놓이게 하였다. 발효시간별로 nylon bag을 꺼내 어 미생물의 성장을 억제하기 위해 얼음물에 즉시 침지시킨 다음 washing machine으로 30 분 간 세척한 후 $80^{\circ} \mathrm{C}$ 의 dry oven에서 48 시간동안 건조하여 중량을 측정하여 건물 분해율을 구하 고, 시료의 성분분석을 위해 nylon bag내의 시 료를 플라스틱 병에 회수하여 분석 시까지 냉 장보관하였다.

3) 반추위 발효성상
반추위 cannula가 장착된 나머지 한우 3두는 반추위 발효성상을 조사하기 위하여 $3 \times 3$ Latin square design에 공시하였다. 각 처리구별로 5 일 간 시험사료에 적응시킨 후 6일째에 8겹의 거 즈를 이용하여 cannula를 통해 각 시간 $(0,1,3$, $5 \mathrm{hr}$ )대 별로 반추위액 채취 즉시, $\mathrm{pH}$ meter를 이용하여 $\mathrm{pH}$ 를 측정하였으며, $\mathrm{VFA}$ 분석용 시 료는 반추위액 $10 \mathrm{ml}$ 당 $\mathrm{HgCl}_{2}$ 포화용액 $1 \mathrm{ml}$ 와 $25 \% \mathrm{H}_{3} \mathrm{PO}_{4}$ 용액 $2 \mathrm{ml}$ 을 넣고 internal standard 로 pivalic acid $0.5 \mathrm{ml}($ Czerkawski, 1976)를 첨가 한 후 $3,000 \mathrm{rpm}$ 에서 20 분간 원심분리한 후 E-tube에 취하여 GC(CP-3800, Varian, USA)로 측정하였다. $\mathrm{NH}_{3}-\mathrm{N}$ 분석용 시료는 반추위액 $10 \mathrm{ml}$ 당 $\mathrm{HgCl}_{2}$ 포화용액 $1 \mathrm{ml}$ 을 취하여 3000 $\mathrm{rpm}$ 에서 15 분간 원심분리한 후 E-tube에 취하 여 Chaney와 Marbach(1962)의 방법에 따라 Spectrophotometer(Spectronic 601, Milton-roy Co., $\mathrm{USA}$ )를 이용하여 $630 \mathrm{~nm}$ 파장에서 분석하였다.

\section{4. 화학성분 분석방법}

섭취사료와 분의 일반조성분은 $\mathrm{AOAC}(1990)$ 법에 의하여 분석하였으며, GE(Gross energy)는 Bomb calorimeter(Parr Instrument Co., USA)를 이용하였다.

\section{5. 통계처리}

본 시험의 성적은 SAS(Statistical Analysis System) 통계 package(2002)를 이용하여 분산분 석을 하였고, Duncan 다중검정으로 유의성검정 을 실시하였다.

\section{III. 결과 및 고찰}

\section{1. 시험사료의 전장소화율과 영양가}

시험사료의 전장소화율과 영양가는 Table 3 에서 보는 바와 같이 현미가 옥수수에 비해 조 지방 소화율은 낮게 나타났으나 $(\mathrm{P}<0.05)$ 다른 성분의 소화율은 차이를 나타내지 않았다. 이 러한 결과는 현미가 옥수수에 비해 조단백질, 
Table 3. Apparent fecal digestibilities of proximate nutrients and nutritive value of experimental diets in Hanwoo steers

\begin{tabular}{lccc}
\hline \multirow{2}{*}{ Items } & \multicolumn{3}{c}{ Brown rice substitution levels for corn (\%) } \\
\cline { 2 - 4 } & & 50 & 100 \\
\hline \hline Digestibility (\%, Dry matter basis) & $70.39 \pm 1.66$ & $73.15 \pm 0.01$ & $70.72 \pm 2.41$ \\
Dry matter & $64.97 \pm 0.48$ & $67.57 \pm 0.26$ & $63.84 \pm 0.88$ \\
Crude protein & $49.56 \pm 0.22^{\mathrm{a}}$ & $49.92 \pm 1.82^{\mathrm{a}}$ & $38.54 \pm 0.13^{\mathrm{b}}$ \\
Ether extract & $65.52 \pm 3.28$ & $66.96 \pm 3.98$ & $65.25 \pm 0.08$ \\
Crude fiber & $33.28 \pm 3.23$ & $33.04 \pm 3.84$ & $33.05 \pm 1.26$ \\
Crude ash & $79.79 \pm 2.60$ & $80.46 \pm 0.02$ & $81.43 \pm 2.62$ \\
Nitrogen free extract & $69.63 \pm 0.75$ & $71.75 \pm 0.22$ & $69.33 \pm 1.33$ \\
Energy & & & \\
\hline Nutritive value ${ }^{1)}$ & $9.52 \pm 0.09$ & $9.71 \pm 0.36$ & $9.11 \pm 0.10$ \\
DCP (\%, Dry matter basis) & $68.01 \pm 1.19$ & $70.86 \pm 1.27$ & $67.21 \pm 2.12$ \\
TDN (\%, Dry matter basis) & $3.11 \pm 0.08$ & $3.16 \pm 0.06$ & $3.06 \pm 0.08$ \\
DE (Mcal/kg) & &
\end{tabular}

1) DCP : Digestible crude protein, TDN : Total digestible nutrients, DE : Digestible energy.

a,b Figures with different superscripts within the same row are significantly different $(\mathrm{p}<0.05)$. Mean \pm standard deviation.

조지방의 소화율이 낮고, 조섬유와 NFE 소화율 이 높게 나타나 있는 일본표준사료성분표(1995, 2001)와 유사한 것으로 나타났다.

\section{2. 옥수수와 현미의 영양가}

전장소화율 시험에서 산출한 현미의 영양가 는 옥수수에 대한 비교값으로서 전반적으로 현 미가 옥수수에 비하여 낮게 측정되었다(Table 4). 한편 일본표준사료성분표(2001)에서는 현미 가 옥수수에 비하여 $\mathrm{TDN}$ 과 $\mathrm{DE}$ 함량이 각각 $92.3: 94.3,4.07: 4.16$ 으로 약간 높게 나타나

Table 4. Calculated nutritive value of brown rice and corn (as dry basis)

\begin{tabular}{lccc}
\hline Items $^{1)}$ & Corn (A) & Brown rice (B) & B/A(\%) \\
\hline \hline DCP (\%) & 6.94 & 6.53 & 94 \\
TDN (\%) & 92.3 & 91.9 & 99 \\
DE (Mcal/kg) & 4.07 & 3.97 & 98 \\
\hline 1) & $\begin{array}{l}\text { DCP : digestible crude protein, TDN } \\
\text { digestible nutrients, DE : digestible energy. }\end{array}$
\end{tabular}

있다. 또한 차 등(1998)이 면양을 이용하여 측 정한 현미의 영양가인 $\mathrm{DCP} 2.96 \%$, TDN $88.84 \%$, $\mathrm{DE} 3.75 \mathrm{Mcal} / \mathrm{kg}$ 에 비하여 본시험에서의 단백질 의 체내 이용성이 특히 높게 평가되었다. 하지 만 이러한 현미의 영양가 차이는 현미의 품종 과 시험축의 차이에 의한 것으로 사료된다.

\section{3. 옥수수와 현미의 in situ 분해율}

반추위내 발효시간별 옥수수와 현미의 분해 율은 Table 5와 같다. 0시간대 건물과 조단백질 분해율 즉 solubility는 옥수수가 현미에 비하여 높았으나 그 후 발효시간별 분해율은 현미가 옥수수에 비하여 높게 나타났다. 한편 차 등 (1998)의 현미의 면양 소화율(건물 $85.4 \%$, 단백 질 $40.9 \%$ )과 비교하여 볼 때 본 시험의 결과에 서 건물의 소화율은 낮았고 단백질의 소화율은 높게 나타났다. 이러한 결과의 차이는 시험에 사용한 현미의 품종(차 등 : 국산 현미, 본시험 : 중국산 도입현미) 및 저장 기간의 차이에 의 한 것으로 사료된다. 또한 본 연구에서 건물의 
Table 5. Ruminal degradability of corn and brown rice (\%, As fed basis) ${ }^{1)}$

\begin{tabular}{|c|c|c|c|c|}
\hline \multirow{2}{*}{ Items } & \multicolumn{2}{|c|}{ Dry matter } & \multicolumn{2}{|c|}{ Crude protein } \\
\hline & Corn & Brown rice & Corn & Brown rice \\
\hline $0 \mathrm{hr}$ & $16.50 \pm 1.16$ & $6.91 \pm 1.04$ & $16.50 \pm 1.20$ & $5.40 \pm 2.21$ \\
\hline $3 \mathrm{hr}$ & $29.49 \pm 9.50$ & $35.16 \pm 4.76$ & $30.07 \pm 8.75$ & $27.75 \pm 5.36$ \\
\hline $6 \mathrm{hr}$ & $32.36 \pm 1.50$ & $50.82 \pm 3.05$ & $34.00 \pm 2.10$ & $40.40 \pm 2.84$ \\
\hline $9 \mathrm{hr}$ & $43.38 \pm 6.51$ & $66.91 \pm 5.19$ & $50.03 \pm 6.16$ & $61.75 \pm 6.97$ \\
\hline $12 \mathrm{hr}$ & $47.82 \pm 4.52$ & $75.15 \pm 7.20$ & $61.79 \pm 4.79$ & $69.68 \pm 6.99$ \\
\hline
\end{tabular}

1) Mean \pm standard deviation

소화율이 낮게 나타난 것은 비교적 낮은 반추 위 내 암모니아태 질소 함량에 기인한다고 추 측된다. 즉, Mehrez 등(1977)과 Leng(1989)은 반 추위내 암모니아태 질소 함량이 $20 \mathrm{mg} / 100 \mathrm{ml}$ 이상의 수준을 유지할 경우 사료섭취량과 소화 율이 최대가 된다고 보고하였다. 본 연구의 반 추위 내 암모니아태 질소 함량은 $12.1 \sim 14.1 \mathrm{mg}$ $/ 100 \mathrm{ml}$ (Table 6)으로 다른 연구 결과에 비해 낮

Table 6. Ruminal fermentation parameters of Hanwoo steers receiving experimental diets

\begin{tabular}{lrrr}
\hline \multirow{2}{*}{ Items } & \multicolumn{3}{c}{$\begin{array}{c}\text { Brown rice substitution } \\
\text { levels }\end{array}$} \\
\cline { 2 - 4 } & 0 & 50 & 100 \\
\hline \hline $\mathrm{pH}$ & 6.05 & 6.05 & 6.00 \\
$\mathrm{NH}_{3}-\mathrm{N}$ (mg/l) & $141.29^{\mathrm{a}}$ & $121.14^{\mathrm{b}}$ & $131.77^{\mathrm{b}}$ \\
Total VFA, mmol & 81.51 & 67.63 & 70.42 \\
acetic acid (A), molar \% & 67.33 & 69.61 & 69.75 \\
propionic acid (P), molar \% & 13.57 & 11.92 & 12.04 \\
iso-butyric acid, molar \% & 1.72 & 1.19 & 1.07 \\
butyric acid, molar \% & 13.12 & 14.07 & 13.97 \\
iso-valeric acid, molar \% & 2.44 & 1.99 & 1.75 \\
valeric acid, molar \% & 1.83 & 1.21 & 1.41 \\
A/P ratio & $4.96^{\mathrm{b}}$ & $5.84^{\mathrm{a}}$ & $5.79^{\mathrm{a}}$ \\
\hline
\end{tabular}

a,b Figures with different superscripts within the same row are significantly different $(\mathrm{p}<0.05)$.
게 나타났다.

\section{4. 시험사료의 반추위내 발효성상}

사료섭취 30 분전과 사료급여 후 $1,3,5$ 시간 의 반추위액 평균 $\mathrm{pH}$ 는 처리구간에 차이가 없 었으나 사료급여 후 시간대로 비교하여 보면 반추위 발효시간에 따른 반추위액의 $\mathrm{pH}$ 변화 는 현미 급여구가 옥수수 급여구에 비하여 3시 간까지 빠르게 떨어지는 경향을 보였고 5시간 에는 유사한 경향을 보였다(Fig. 1). 이러한 결 과는 현미의 반추위내 소화율이 옥수수에 비해 빠른 것에(Table 5) 영향을 받은 것으로 사료된 다.

일일 평균 반추위액 암모니아 농도는 옥수수 를 현미로 대체 시 낮아졌으며 $(\mathrm{P}<0.05$; Table 6$)$, 이것은 유사한 시험을 수행한 吉田 등(1985)의

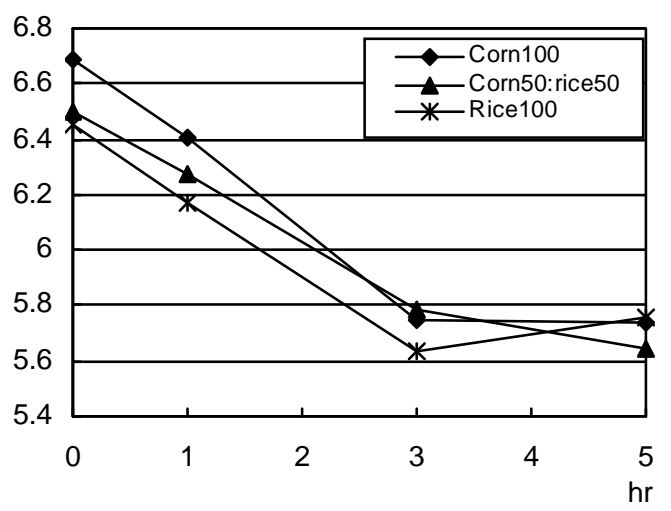

Fig. 1. Change of ruminal $\mathrm{pH}$ of treatments by fermentation time. 
결과와 같았다. 吉田 등(1985)은 현미구에서 암 모니아 농도가 낮게 측정된 것은 섭취사료 내 단백질의 농도보다는 현미급여에 따른 프로토 조아의 증가가 원인일 것으로 추정하고 있으 며, 井上 등(1985)과 丸山 등(1984)도 현미를 급 여 시 프로토조아의 수가 증가하였다고 보고한 바 있다. 본 연구에서도 현미 급여에 따라 휘 발성지방산의 생성비율 중 초산의 비율이 높아 지고 프로피온산의 비율은 감소하는 조사료적 인 결과를 보임에 따라 현미구에서 프로토조아 가 증가했을 것으로 추정할 수 있다(McAllister 등, 1990). 한편 사료급여 후 시간대별 반추위 액의 암모니아 농도 변화에서도 Fig. 2에서 보 는 바와 같이 발효 후 빠른 시간대(1,3시간)에 현미 급여구가 옥수수 급여구보다 낮게 나타났 다. 일반적으로 사료 내 단백질 함량이나 용해 도 및 사료의 물리-화학적 특성에 따라 반추 위내 암모니아 농도 수치는 크게 영향을 받는 다(Henning 등, 1993). 따라서, 현미 급여로 인 한 용해도 증가 $(\mathrm{pH}$ 저하)가 발효초기 에너지 공급증가로 암모니아 농도 저하에 영향을 미친 것으로 사료된다.

반추위 내 총 휘발성지방산 함량은 옥수수 $100 \%$ 구에서 현미 급여구에 비하여 수치적으로 높게 나타났으나 시험축 분석치 간의 변이차가 커서 통계적인 유의차는 인정되지 않았으며, 휘발성 지방산 조성에 있어서도 통계적 유의성은 없었 으나 현미 급여구에서 초산은 증가하는 경향을 보였고 프로피온산은 감소하는 경향을 보였다.

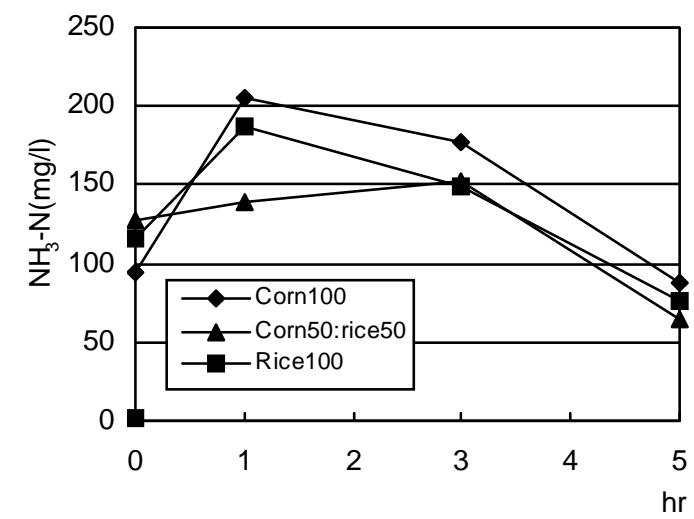

Fig. 2. Change of ruminal $\mathrm{NH}_{3}-\mathrm{N}$ concentrations of treatments by fermentation time.
따라서 반추위액의 초산/프로피온산(A/P) 비율 은 Fig. 3에서 보는 바와 같이 현미 급여구가 옥수수 급여구에 비하여 유의적으로 증가하여 $(\mathrm{p}<0.05)$ 현미의 가용성 탄수화물의 반추위 내 이용패턴이 옥수수와 다르다는 것을 보여준다. 丸山 등(1984)는 반추위내 발효성상에 미치는 현미 급여결과에서 $\mathrm{pH}, \mathrm{NH}_{3}-\mathrm{N}$, 초산(A), 프로피 온산 $(\mathrm{P})$ 함량과 $\mathrm{A} / \mathrm{P}$ 비 간에 차이가 없었다고 하 여 본 연구결과와 상이하였으나, 井上 등(1985) 은 현미 급여가 초산의 농도를 높이고, 프로피 온산 농도를 감소시키는 조사료적인 특징을 보 였다고 보고하였다. 이와 같이 현미 급여에 따 라 초산의 비율이 높아지고 프로피온산의 비율 은 감소하는 조사료적인 결과를 보임에 따라 곡류 내 가용성탄수화물의 이용성에 대한 다양 한 연구가 수행되어야 할 것으로 사료된다. 일 반적으로 반추위 내에 휘발성지방산은 반추동 물의 주요 에너지원이며(Casper 등, 1990), 휘발 성지방산의 생산량 및 생산 비율은 사료의 조성, 급여량, 급여 방법 등에 영향을 받는다(McCarthy 등, 1989; Overton 등, 1995). 한편 branched chain fatty acid(BCFA)인 iso-butyric acid와 iso-valeric acid의 반추위 내 농도에서 통계적 유의성은 없 었으나 현미 급여구에서 낮아지는 경향을 보였 다. Bryant(1973)는 BCFA의 탄소골격은 섬유소 분해박테리아의 성장에서 branched chain amino acid의 합성에 이용됨을 보고하였다. 따라서 반 추위 내 BCFA 농도가 낮으면 미생물 성장을 제한한다고 하였다(Cline 등, 1966). 따라서 본

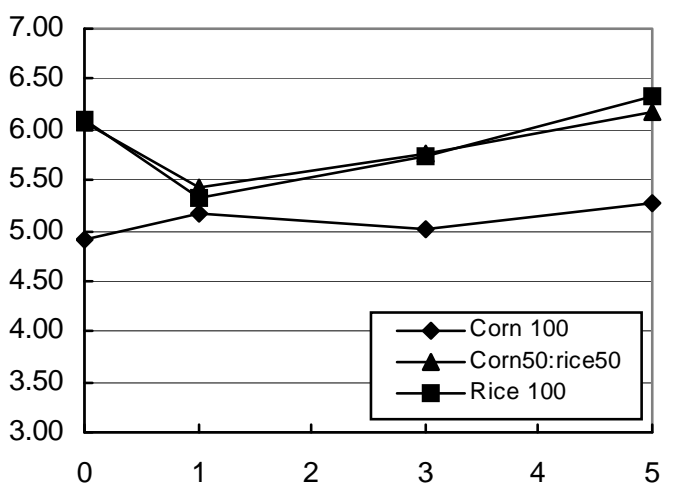

Fig. 3. Change of ruminal A/P ratio of treatments by fermentation time. 
연구에서 현미 급여구의 비교적 낮은 BCFA 농 도는 미생물 성장을 억제하여 낮은 암모니아태 질소량과 낮은 건물 소화율에도 일부 영향을 미쳤을 것으로 사료된다.

$$
\text { IV. 요 약 }
$$

현미의 한우에 대한 사료가치 평가를 위해 옥수수 50\%와 $100 \%$ 를 현미로 대체한 배합사료 의 반추위 발효성상, in situ 영양소 분해율, in vivo 전장소화율을 측정한 바 결과는 다음과 같 다.

옥수수와 현미의 체내 영양소 소화율과 영양 가는 유사하였으나 반추위 내 분해율은 현미가 옥수수에 비하여 빠르게 나타났다. 옥수수와 현 미가 함유된 시험사료를 급여한 후 반추위 $\mathrm{pH}$ 는 시험사료 간 차이를 보이지 않았으나 $\mathrm{NH}_{3}-\mathrm{N}$ 농도는 현미 급여수준이 증가할수록 낮 아졌다 $(\mathrm{P}<0.05)$. 반추위액의 총휘발성지방산 함 량은 옥수수구가 현미구에 비하여 높게 나타났 으며, 초산과 프로피온산 비율(A/P)은 옥수수구 에 비해 현미를 급여한 구에서 높은 수치를 보 였다 $(\mathrm{P}<0.05)$.

이러한 결과를 볼 때 소 사료에 옥수수를 대 체하여 현미를 사용하는 것에 영양학적으로 문 제가 되지 않으며, 특히 곡류사료 위주 사양체 계 하에서 낮은 초산과 프로피온산 비율에 대 한 현미의 긍정적인 효과가 기대되어 이러한 곡류 내 가용성탄수화물의 이용성에 대한 다양 한 연구가 수행되어야 할 것으로 사료된다.

\section{$\mathrm{V}$. 인 용 문 헌}

1. A.O.A.C. 1990. Offical method of analysis, association of offical agricultural chemist. Washington, D. C. USA.

2. Bryant, M. P. 1973. Nutritional requirements of the predominant rumen celluloytic bacteria. Fed. Proc. 32:1809.

3. Casper, D. P., Schingoethe, D. J. and Eisenbeisz, W. A. 1990. Response of early lactation dairy cows fed diets varying in sources of nonstructural carbohydrate and crude protein. J. Dairy Sci. 73:1039.

4. Chaney, A. L. and Marbach, E. P. 1962. Modified reagents for determination of urea and ammonia. Clinical Chemistry. 8:130-132.

5. Cline, T. R., Garrigus, U. S. and Hatfield, E. E. 1966. Addition of branched and straight chain volatile fatty acids to purified lamb diets and effects on utilization of certain dietary components. J. Anim. Sci. 25:734.

6. Henning, P. H., Steyn, D. G. and Meissner, H. H. 1993. Effect of synchronization of energy and nitrgen supply on ruminal characteristics and microbial growth. J. Anim. Sci. 71:2516-2528.

7. Leng, R. A. 1989. In ruminant physiology and nutrition in Asia(Eds. C. Devendra and E. Imaizumi). Jap. Soc. Zootech. Sci.

8. McCarthy, R. D., Klusmeyer, T. H., Vicini, J. L., Clark, J. H. and Nelson, D. R. 1989. Effects of source of protein and carbohydrate on ruminal fermentation and passage of nutrients to the small intestine of lactating cows. J. Dairy Sci. 72:2002.

9. McAllister, T. A., Rode, L. M., Major, D. J., Cheng, K. J. and Buchanan Smith, J. G. 1990. Effect of ruminal microbial colonization on cereal grain digestion. Can. J. Anim. Sci. 70:571.

10. Mehrez, A. Z., Orskov, E. R. and McDonald, I. 1977. Rates of rumen fermentation in relation to ammonia concentration. Br. J. Nutr. 38:437.

11. Overton, T. R., Cameron, M. R., Elliott, J. P., Clark, J. H. and Nelson, D. R. 1995. Ruminal fermentation and passage of nutrients to the duodenum of lactating cows fed mixtures of corn and barley. J. Dairy Sci. 78:1981.

12. SAS. 2002. Sas User's Guide. Statistics. Version 8.e. SAS Institute. Inc. Cary, NC.

13. 吉田茂昭, 宗石忠信, 高葛孝一, 富田正信. 1985. 飼料米給與が乳用牛の第一胃内および血液性狀 に及ぼす影響。福井縣畜産試驗場呼究報告第 9 号: 23-34.

14. 日本標準飼料成分表. 1995. 農林水産省農林水産 技術會議事務局. 
15. 日本標準飼料成分表. 2001. 農林水産省農林水産 技術會議事務局.

16. 井上直人, 吉田宮雄, 伊藤 降, 平方明男, 萩原 宗弶. 1985. 飼料用モミの給與が乳牛の産乳性と ルーメン內性狀に及ぼす影響。長野縣畜産試驗 場研究報告第20号: 14-22.
17. 丸山國美, 長妻義孝, 入江 壯. 1984. 乳牛におけ る飼料米給與技術に關する試驗。埼玉縣畜産試 驗場研究報告第22号: 1-9.

18. 차영호, 김형호, 박준철, 정완태. 1998. 면양의 사 료로서 벼, 현미, 백미의 가소화영양성분. 축산논 문집. 40(1):114-117.

(접수일자 : 2005. 12. 28. / 채택일자 : 2006. 5. 24.) 